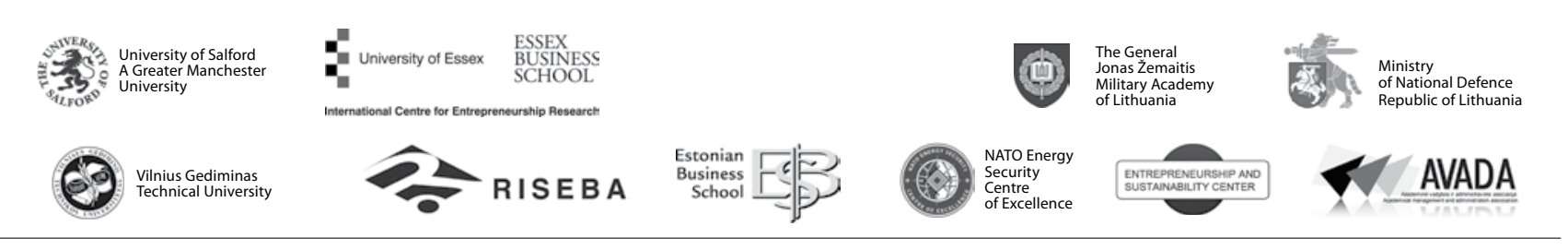

\author{
JOURNAL OF SECURITY AND SUSTAINABILITY ISSUES \\ ISSN 2029-7017 print/ISSN 2029-7025 online \\ 2017 March Volume 6 Number 3 \\ http://dx.doi.org/10.9770/jssi.2017.6.3(4)
}

\title{
TOWARDS ENHANCED SECURITY: DEFENSE EXPENDITURES IN THE MEMBER STATES OF THE EUROPEAN UNION
}

\author{
Radoslav Ivančík ${ }^{1}$, Pavel Nečas ${ }^{2}$ \\ ${ }^{1}$ Ministry of Defence of the Slovak Republic, Kutuzovova 8, 83247 Bratislava, Slovakia \\ ${ }^{2}$ University of Security Management, Koštova 1, 04001 Košice, Slovakia \\ E-mails:1radoslav.ivancik@gmail.com; ${ }^{2}$ pavel.necas@vsbm.sk
}

Received 20 August 2016; accepted 19 October2016

\begin{abstract}
Ensuring the defence of freedom, independence, sovereignty, territorial integrity, and population belongs to the main tasks of each state. Therefore, countries, in response to the current political, security and economic situation, must earmark, within the framework of their national budgets, a proportion of the available resources to ensure their defence. The aim of the article, based on current trends in the defence budgets of the European Union member states, is point out that not only the global economic and financial crisis and the credit and debt crisis in the euro area have a significant negative impact on the amount of resources, which individual European Union member states earmark to ensure their defence.
\end{abstract}

Keywords: defence, security, defence expenditure, European Union, member states.

Reference to this paper should be made as follows: Ivančík, R.; Nečas, P. 2017. Towards enhanced security: defense expenditures in the member states of the European Union, Journal of Security and Sustainability Issues 6(3): 373-382.

http://dx.doi.org/10.9770/jssi.2017.6.3(4)

JEL Classifications: E00, E69, H40, H56

\section{Introduction}

Prosperity, development, and sustainable growth of living standards has never been in the past so significantly dependant on the level of state and citizen security as it is nowadays in the currently economically interconnected and rapidly changing world in response to the deepening exchange and flow of information, capital, transactions, goods and services, intensive socio-cultural contacts and legal and illegal immigration (e. g. Beifert 2015; Vaško, Abrhám 2015; Rezk et al. 2015; Ahmed et al. 2017; Mouraud 2017; García-Fuentes, De Torre 2017; Daher et al. 2017; Gasparènienè et al. 2017; Dirzytė et al. 2017).

The emergence of new, especially asymmetric security threats and their proliferation following the fundamental changes in the worldwide security environment after the end of the Cold War, the fall of the Iron Curtain and the resultant decomposition of the world significantly shaped the view on ensuring defence and security.

In this context, we would argue that the government probably all the countries of the world, the EU Member States certainly, did not avoid the new requirements on sufficient military capacity and capability disposal as well as the ability to react on the current and newly resurfacing security threats. For these reasons, the importance of defence planning has been increasing in the respective countries, what constitutes a specific process, via which each state or coalitions of states accomplishes its function of operation and coordination by creating, 
maintaining and applying inevitable defence capacities for ensuring state defence and meeting international commitments for the purpose of defending freedom, independence, sovereignty, territorial integrity, the principles of democratic constitutional order and the life and property of citizens.

The primary objective of this article is to bring a theoretical view of the concept of funding defence as one of the public goods (financed from the public budget) in the context of empirical data of defence spending in the EU Member States. Partially, the article via comparison of defence expenditures in the European countries exhibits a possible decrease in stability of the security environment regarding the reduction in defence expenditure.

Among the main methodological approaches enforced in this study belong the economic theory of public goods, comparative and trend analysis, since its analysis is going to be applied on the expenditure connected with ensuring defence from public resources along with utilizing comparison of defence spending among the monitored states. In the first part of this study we are going to concentrate on the very theoretical definition of defence in terms of the economic theory. In the second part, we are going to focus on the mutual comparison of defence spending in the North American and European NATO Member States.

In the processing of this study, we have used as a starting material the works of influential economists J. E. Stiglitz (1997) and P. Samuelson \& W. Nordhaus (1992), who claim that nothing is as important for society as its defence and security. Neither economy nor society can prosper unless these are guaranteed by the state. During the preparation of this article, very useful were also the publications of other reputable authors such as A. Smith (2001), G. Kenneddy (1993), and H. Kanter (1984), who in their works highlight the importance of economies of defence in practice and its impact on society and its security. From the domestic, Slovak sources, we have used mainly work of J. Medved’ \& J. Nemec et al. (2011), R. Ivančík (2012), J. Lasicová \& J. Ušiak (2012) or Kazanský (2015) which stress the necessity of ensuring national defence and security for the peaceful development of society and the interconnection of the economy and national defence.

In the processing of the analysis of current trends in defence expenditure, we also used the most recent data from the European Defence Agency (EDA) and Stockholm International Peace Research Institute (SIPRI), confirming the close link between defence and economy. The importance of the issue also lies in proving a direct link between the level of defence spending and the level of stability of the security environment not only in individual countries but in the European Union as a whole.

\section{Defence as a public good in the economic theory}

Ensuring defence as a public good and an indispensable part of public sector belongs among the basic tasks of a state. At the same time, defence also belongs among the very basic economic activities of the state, since for the fulfilment of these tasks a state spends a part of its human, material and financial resources. New security risks along with the change of character and form of threats require that the states adopt, except for a number of political, military, organizational and legislative measures, adequate economic measures as well (Ivančík, 2012). The issue of national defence is also an economic issue (Hitch \& McKean, 1975). History confirms that demands on the economic security of state defence and life protection have been constantly increasing along with the development of human society. Because of that fact, from the overall summary of factors influencing the needs of defence, economy acts as a decisive factor. Economy in fact represents a basis of state defence as it secures it with the necessary resources.

Along with solving the issue of state defence society has to deal with the issue of peaceful state development. Limited and precious economic resources have to be divided into peaceful and defensive and depending on the situation or the character of the threat the state has to try to optimize the choice between peaceful and defensive expenditures. This fact should get currently even more to the forefront, when the consequences of the recent global economic and financial crisis and the currently ongoing loan and debt crisis were added to the list of new security threats of the 21 th century. That is why the problems of economic security of defence and its financing require incomparably greater attention than before (Ivančík, 2012). 
Defence and security should not thus be dependent on market fluctuations. On the contrary, economic security of defence and state security should be stable, since in time of crisis and uncertainty the feeling of danger is more intense and the demand for defence and security increases. From the point of view of economic theory we can regard defence as an integral part of public sector. One of the first comprehensive definitions of public sector in our conditions says that public sector represents that part of national economy which is financed by public finances, managed and administered by public administration, is subject to public control and where decisions are taken by public choice (Strecková, 1998).

From the perspective of Anglo-Saxon literature, this is also valid in our conditions, the mostly cited work is written by J. E. Stiglitz (1997), who emphasizes that in civilized states the activity and decisions of the government significantly influences the citizens' lives and not only in the field of education, healthcare, housing or employment, but also in the sphere of securing state and citizens' defence, which is ensured via specific public sector institutions.

The neoclassical economy is based on the fact, that the public sector, which is financed by public finances, plays a very important role as well as a constructive task in the economy. This was already emphasized by A. Smith (2001), who pointed out the basic tasks of the state in the economy, while he regarded the task of ensuring defence and security of the citizens as crucial. At the same time, the inevitability of state interventions for ensuring defence and security of citizens is accented in all consequent economic theories dealing with the issue of public sector and public finances (Ivančík, 2012). If the public sector ensures public goods, the emphasis is based on the economic substance and not on its institutional manifestations. Public goods have two main characteristics: non-excludability (this occurs when it is not possible to provide a good without it being possible for others to enjoy) and non-rivalry (this means that when a good is consumed, it doesn't reduce the amount available for others). Based on this defence is one of the few cases of pure public good (Stiglitz, 1997).

Ensuring defence belongs among the typical examples of public goods. Benefit from these goods is so scattered among the citizens that no single firm or consumer has economic motivation to provide them complexly and systematically. In this regard Samuelson and Nordhaus (1992) claim that nothing is more important for society as its defence and security. Defence as a collective good cannot be divided into partial units, since each individual consumes it in bloc. Benefit (utility), what the individual receives from it does not reduce benefit (utility) for the other members of society. Because of that, according to many authors, the marginal costs of additional consumption are in case of defence zero.

In terms of expenditure height is ensuring defence or another collective good, for example the usage of naval navigation, equal regardless of the fact, if defence makes use of 999 thousand or 1 million citizens of the state, respectively if around the lighthouse on the coast sail 50 or 100 ships. In the first case, the armed forces of the respective state ensure defence, which serves all citizens of the state and from which it is not allowed to exclude anyone. In the second case, by using naval navigation the lighthouse shines equally for all ships, which sail along regardless of the fact if their owners contributed to its construction or not (Sivák et al., 2007).

Following the narrow interrelation of public sector with the state's performance of tasks, defence ensures the output of the security-defence function of the state. In the frame of public sector division defence, which satisfies the needs of state and its citizens' security, belongs to the group of society needs segments (Strecková, 1998). From the perspective of ,public interest“" is thus defence beneficial for all citizens of the state, as benefit from it has each single citizen. Ensuring public goods represents an economic activity bringing benefit for the society, which cannot be left to private entrepreneurship. Considering the aspect of excludability and impossibility of measuring individual consumption, defence and other similar goods, for example security, are directly predetermined to be a subject of public financing (Medved' \& Nemec et al., 2011).

Private initiative is not sufficient in these cases. At the same time it is highly improbable that people provide on the basis of voluntariness sufficient resources from their pensions to ensure defence or other public goods, and therefore it is inevitable that the state secures these from public resources. As the state decides within its 
performance of functions on the fields, to which, including defence a disposable part of resources will be channelled, and also ensures that goods and services, which the state buys for securing its own defence are truly produced and realized.

Claims on economic securing of liberty, independence, sovereignty and territorial integrity of a state, but also the lives and property of citizens have been permanently increasing with the development of human society and economy has gradually become a decisive factor in securing defence. Dependence of building military state power on the economy has gradually become a lot stronger than before, because of the fact that it is proportional to the possibilities of the respective state economy, i.e. the size of gross domestic product, the rate of economic growth, the rate of work productivity growth, its sectorial and spatial structure, its elasticity and ability to react on the newest trends in the field of scientific and technological development and in the recent years also on the changes resulting from globalization and its negative impacts on defence and security (Ivančík, 2012).

Economy, in case of defence, defines the possibilities of a country especially in the field of building and forming armed forces, their structure, quantitative and qualitative level of military and civil personnel, quantity and quality of armament and equipment, training, technical preparation, material maintenance, possibilities and means of conducting an armed struggle or securing defence etc. The power of the country's economy significantly influences the economic and material maintenance of securing defence, preparation, and course and to a considerable extent also the overall outcome of an armed struggle. The economic development of a country, resp. a coalition plays a decisive role by creating military-strategic conceptions, which have to respect real economic possibilities (Šefčík, 1999).

Ensuring defence also has a backward impact on the economic development of society, as it withdraws society a huge part of means and powers, which are consequently in national economy not being used for production of new peaceful economic goods (grocery, automobiles, electronics, furniture, clothing, medicaments etc.), but for purchasing and introducing new types of armed technique, weapons, weaponry systems and their modernization and maintenance.

\section{Current trends in defence expenditure in EU Member States}

Banking sector crisis and the subsequent economic and financial crisis, which broke out first in the United States of America (further only „USA“) and then expanded to the entire world, started a period of economic recession, that does not have any equivalent since the Second World War. With no exception of the USA no-one could escape the negative impact of the global economic and financial crisis, gradually because of the deepening globalization, including the EU Member States.

Considerable reduction of the rate of economic growth, increase in unemployment rate, growth of budget deficits, worsening of paying balance and other negative impacts of the crisis, including the debt and loan crisis in the Eurozone caused that each government had to and still has to via public expenditure adopt more penetrative or slighter economic, but also political and legislative measures in order to mitigate the impacts of the crisis. One of the first steps, to which the majority of the countries have resorted, is the effort to consolidate public finances via introducing financial restrictive measures in relation to the state budget. From the economic point of view, the reasons are clear, decreased economic activity leads to decreased income of the state budget.

Budget mathematics is also merciless. Drop-outs on the side of income bring drop-outs on the side of expenditure. Planned and in advance approved budgets seem because of this reason as unsustainable and if the respective states within responsible fiscal policy do not want to increase their debts and via subsequent loans compensate the drop-outs in income, they have to execute cuts. Although unpopular, but inevitable, as the use of foreign loans for financing expenses in state budget incomes would not bring anything else but increase of the countries' foreign debts, what represents unwanted and from the long-term point of view unsustainable phenomenon. 
Therefore cuts are necessary especially in the fields that are not regarded as priorities in the respective countries. In the majority of states, including the EU Member States, the first victim of saving became the expenses for ensuring defence. However, not in every country. In some of them, for example in the BRICS states, defence has remained despite the crisis a priority (see Graph 1), as economic securing of defence should be also in times of crisis stabile, since in times of crisis and uncertainty the feeling of danger is more intense and the meaning of securing defence increases.

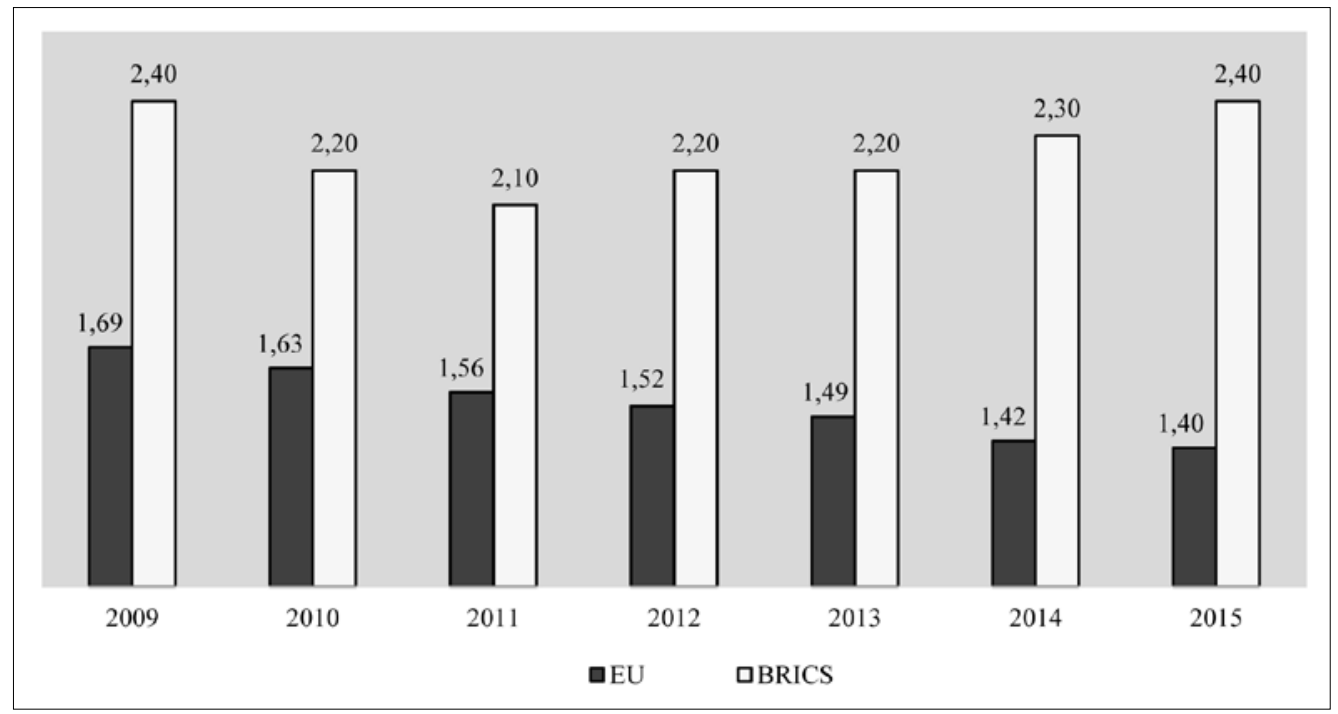

Graph 1. Trend in Defence Expenditure in the EU countries and the BRICS countries in the years 2009-2015 (as \% of GDP).

The difference in the approach towards securing defence can be observed not only among diverse countries of the world, but also within EU. Whereas only four member states (Greece, Great Britain, Estonia and Poland), following the worsening global and regional security situation, maintain their defence expenditure even despite the global economic and financial crisis above the level of $2 \%$ GDP, which is generally considered sufficient in peacetime, many member states (Austria, Belgium, Czech Republic, Hungary, Ireland, Luxembourg, Malta, Slovenia and Spain) earmark for defence less than 1\% of GDP (see Graph 2).

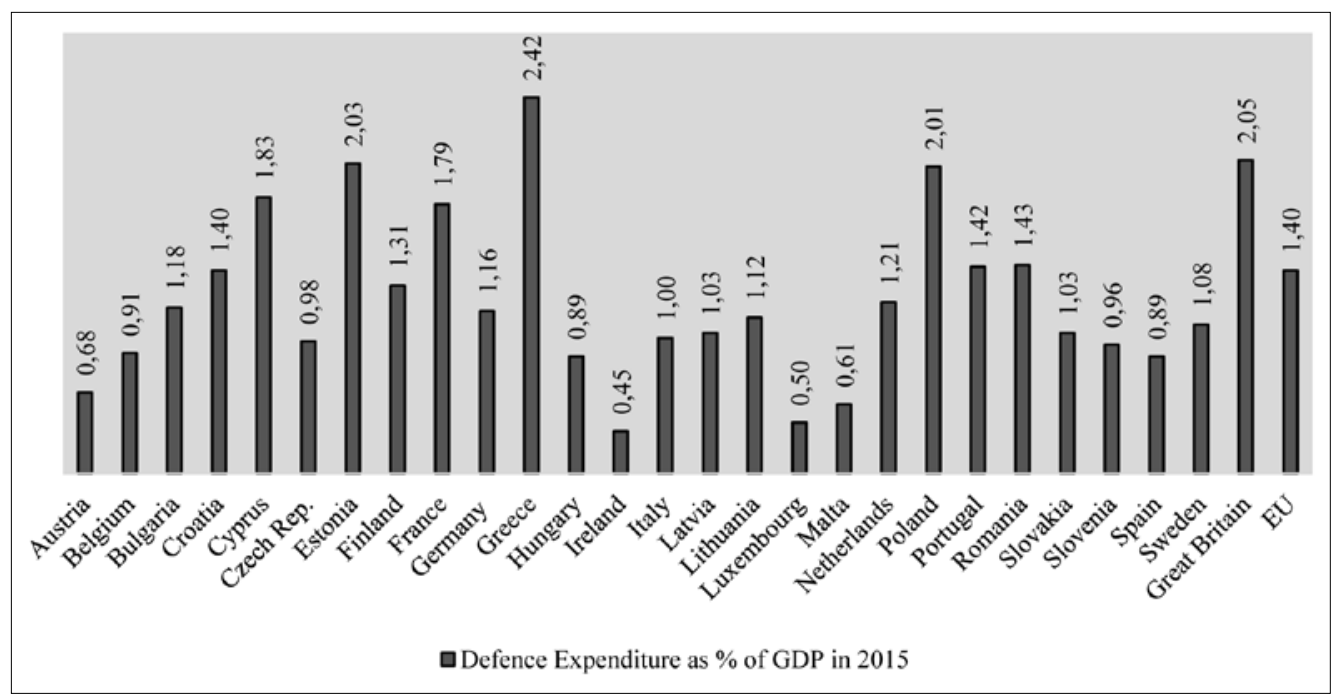

Graph 2. Trend in Defence Expenditure in the EU Member States in 2015 (as \% of GDP). 
The above graph 2 clearly shows that the differences between the member states of the Union are quite substantial. Total average defence expenditure in EU Member States (except Denmark, which does not participate in the Common Security and Defence Policy) in 2015 reached the level of 1.40\% of GDP. However, the problem is not only lack of expenditure on defence, but an even greater problem is that this level (with the exception of 2009 when there was considerable decline in GDP because of the impact of the global economic and financial crisis) is decreasing in recent years (see Graph 3).

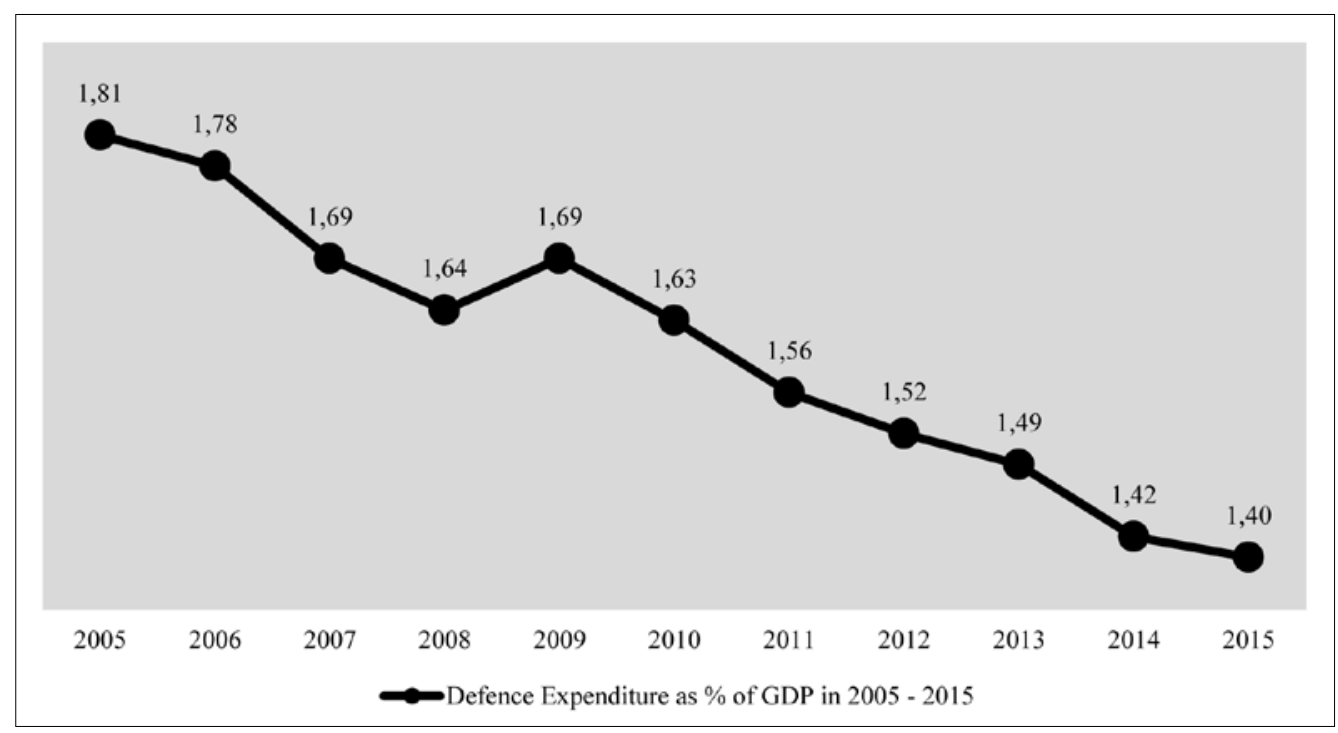

Fig. 3. Trend in Defence Expenditure in the EU Member States in the Period 2005-2015 (as \% of GDP)

Source: EDA, 2016

Based on Graph 3, it can be said that the downward trend of defence expenditure is not directly related to the global economic and financial crisis or debt and loan crisis, although, in most member countries, the crisis could have the impact on the increasing difference from the boundary of $2 \%$ of GDP, to which those European Union member states, which are also NATO members, committed. In the case of the some mentioned countries, it can be also said that they use, or (according to some security experts and politicians) abuse benefits and advantages of collective defence within Alliance and Union.

The NATO Secretary General expressed himself to the above mentioned problem during his visit of Slovakia. He said that "It is understandable that increasing the defence budget is not easy and the question of increasing the resources for the armed forces is currently very sensitive. However, the current crisis in Ukraine clearly demonstrates that defence is still extremely important." He emphasized: "Defence costs something, but if it was not secured, it would cost even more". At the same time in this regard, the chief of the North-Atlantic Alliance appealed to the especially European members of the Alliance to meet their commitment in spending 2\% GDP on defence.

Proponents of the approach based on the (1) acceptance of own responsibility for security in Europe and (2) the end the reliance on the United States displease figures referring to the level of defence spending as a proportion of total government spending in European Union member states (Graph 4).

On this graph, it is possible to observe the impact of the global economic and financial crisis and the credit and debt crisis in the euro area countries on the defence budgets. According to the data, we can also observe as decreased performance of the economy during recession brings smaller volume of GDP and thus also a noticeable drop in defence expenditure. On the other hand, making excuses for the lingering effects of the global financial crisis and other financial crisis does not stand up because Graphs 3 and 4 show that in the countries of the Union defence spending fell even before the outbreak of the aforementioned crisis, which just goes to show that the defence and security are really not a priority in the Union. 


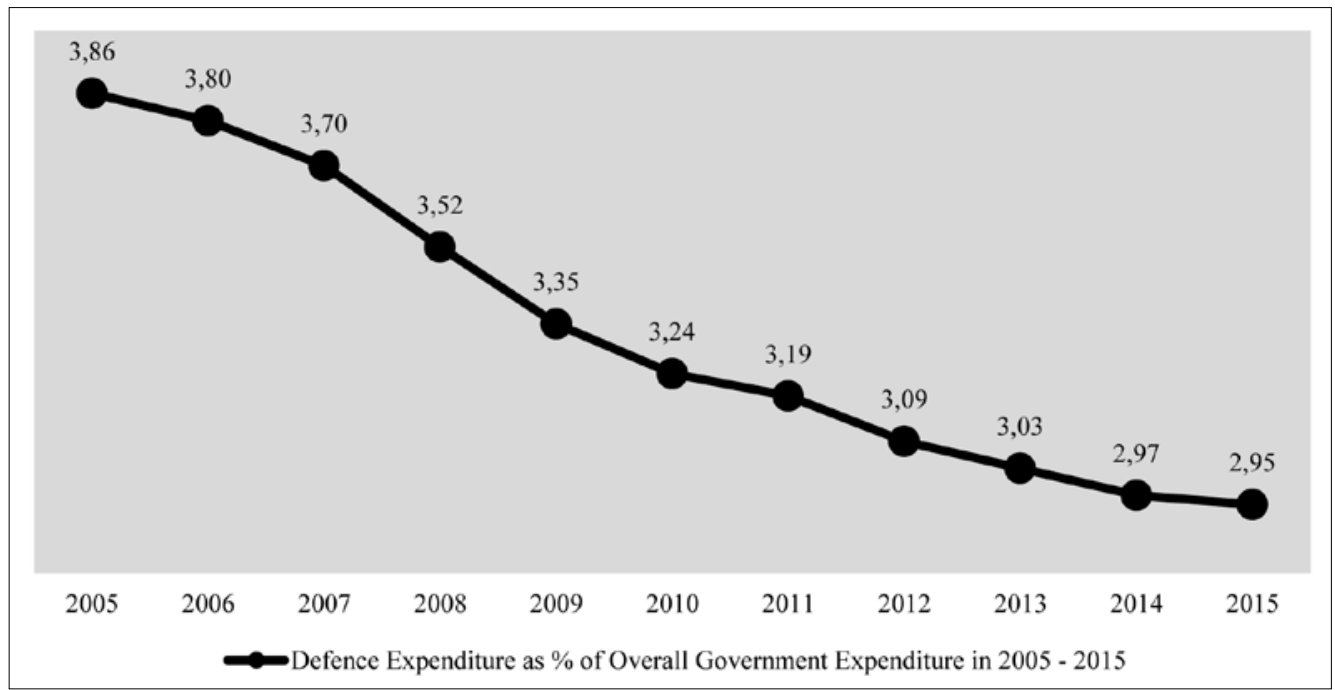

Fig. 4. Trend in Defence Expenditure as a Proportion of Overall Government Expenditure in EU Countries in the Years 2005-2015 (in \%).

Source: EDA, 2016

The analysis of trend in defence expenditure development, following the above listed, thus points out the fact that significant drop in defence expenditure occurs, and this is true towards the GDP as well as in terms of proportion to total government expenditures, in the economically and militarily strong and by area and population size big countries as well as in the traditionally, economically and militarily not so strong and by area and population size not so big EU Member States. Their defence budgets have thus gradually even more moved away from the limit of $2 \%$ GDP, which is generally considered an adequate level of defence spending. Another negative aspect is the fact that except of overall decline in defence expenditures there is also considerable decline in investments in new defence projects, research and development in recent years (except in 2010) (see Graph 5).

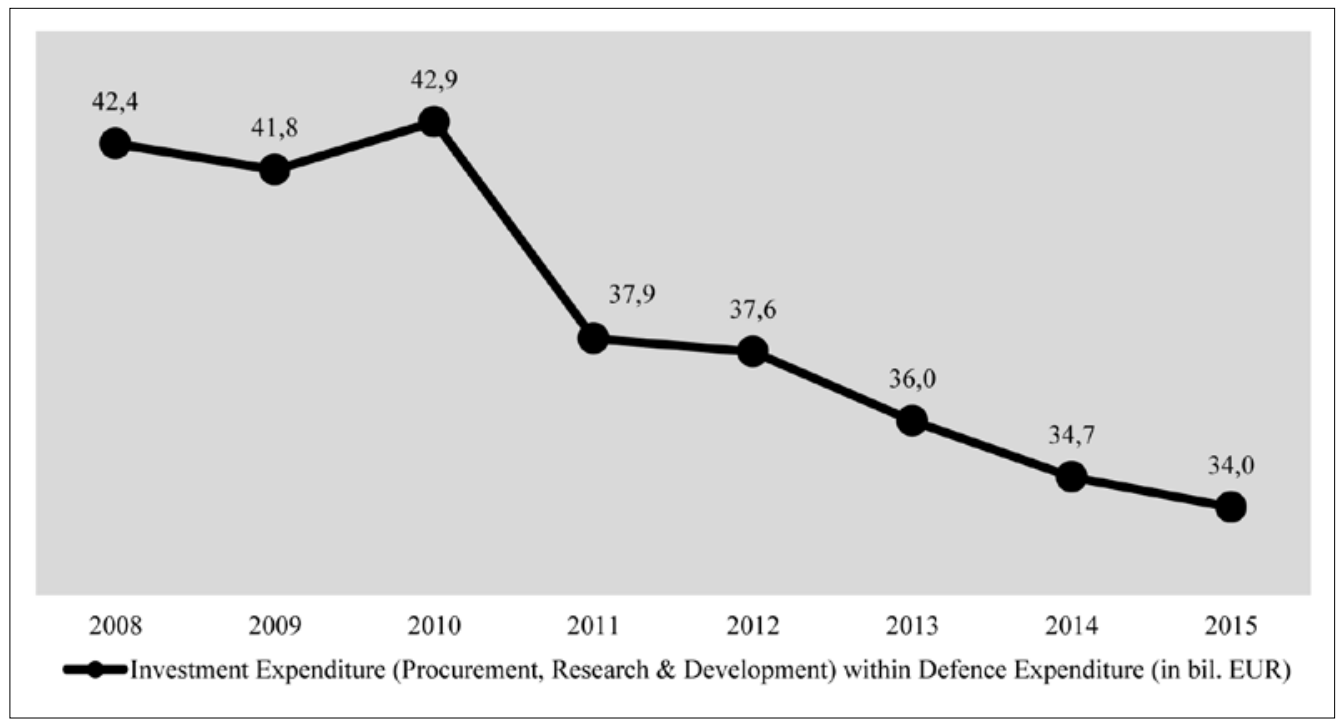

Fig. 5. Trend in Investment Expenditure (Procurement, Research \& Development) as a Part of Defence Expenditure 2005-2015 (in bil. EUR)

Source: EDA, 2016 


\section{Conclusions}

Increasing demands of defence on the economy, influenced by mainly political and military factors, impact on restricted possibilities of the economy, but in spite of that the current character of defence requires that the respective states, alternatively coalitions concentrate except securing the above mentioned demands of defence also on the protection of their economic resources against attacks of opponents and at the same time exploit all available means to weaken his economic strength. Mutual relations of defence and economy have been permanently developing, deepening and are gradually narrower and interconnected. Because of that the issue of defence currently requires more interest as before.

Except dynamic changes in other fields, changes occurred also in economic securing of defence. The above listed graphs confirm that the global economic and financial crisis has unquestionably negative impact on securing defence and singling out expenditure for defence from the state budget of the respective states. On the basis of investigating several available relevant information, facts and characteristics it is not possible to conclude one definite deduction that precisely the crisis represents that main reason, for what in the majority of the EU member states a drop in defence expenditure has occurred.

As it was indicated above, the global economic and financial crisis or debt and loan crisis cannot be marked as the main trigger of decreasing defence budgets in EU member states, since decreasing tendencies in defence expenditure development have significantly manifested itself in majority countries for a longer period, not only in the period after the outbreak of the crisis. Other factors also influenced the drop in defence expenditure.

Some countries, in terms of economic theory, took the position of "free riders" and began to rely more on the fact that the other members of the European Union or North-Atlantic Alliance will account to pay. It is clear that in many countries a change in their defence policy occurred after the removal of the immediate threat of conflict between the East and the West in Europe on the European territory and another countries changed their attitude of their political representation, which by the non-existence of direct military threat were not able to enforce that height of means in their national parliaments by voting on state budget. And from the above graphs and data, it is clear that they are also not able to do it at present, when there is a real deterioration in the global and continental security environment and the growth of security threats. It simultaneously means that their armed forces do not have enough resources not only for more extensive modernization, but also for training and maintenance all the previously built military capabilities and capacities.

From the analysis of defence expenditure trends in EU member states results that while among some members securing their own individual and collective defence and national as well as European Union interests remained also despite the crisis a high priority, among some members of Union defence has gradually stopped to represent a priority and defence expenditures have become after the breakout of global economic and financial crisis and during loan and debt crisis the first victim of saving. Reduction of defence budgets in majority of EU member states have also fundamentally influenced the overall trend of defence expenditure in the European Union as a whole, since the reasons are not only economic, but also political and they are narrowly connected with the shortage of cohesion of the entire EU defence strategy within Common Security and Defence Policy.

\section{References}

Ahmed, A.; McGough, D.; Mateo-Garcia, M. 2017. Testing innovative technologies for retrofitting: Coventry University as a living lab, Entrepreneurship and Sustainability Issues 4(3): 257-270. http://dx.doi.org/10.9770/jesi.2017.4.3S(2)

Beifert, A. 2015. Business development models for regional airports - case studies from the Baltic Sea region, Journal of Security and Sustainability Issues 5(2): 199-212. http://dx.doi.org/10.9770/jssi.2015.5.2(6)

Besenyő, J. 2015. Not the invention of ISIS: Terrorists among immigrants, Journal of Security and Sustainability Issues 5(1): 5-20. http://dx.doi.org/10.9770/jssi.2015.5.1(1)

Daher, E.; Kubicki, S.; Guerriero, A. 2017. Data-driven development in the smart city: Generative design for refugee camps in Luxem- 
bourg, Entrepreneurship and Sustainability Issues 4(3): 364-379. http://dx.doi.org/10.9770/jesi.2017.4.3S(11)

Dirzytė, A.; Rakauskienè, O. G.; Servetkienė, V. 2016. Household income and satisfaction with life: cognitive - emotional impact paradox, Entrepreneurship and Sustainability Issues 4(2): 198-210. http://dx.doi.org/10.9770/jesi.2016.4.2(7)

EDA. 2016. Defence Data Portal. Available on the Internet: <https://www.eda.europa.eu/info-hub/defence-data-portal>

García-Fuentes, M. A.; De Torre, C. 2017. Towards smarter and more sustainable regenerative cities: the REMOURBAN model, Entrepreneurship and Sustainability Issues 4(3): 328-338. http://dx.doi.org/10.9770/jesi.2017.4.3S(8)

Gasparènienè, L.; Remeikienè, R.; Sadeckas, A.; Ginevičius, R. 2016. Level and sectors of digital shadow economy: the case of Lithuania, Entrepreneurship and Sustainability Issues 4(2): 183-197. http://dx.doi.org/10.9770/jesi.2016.4.2(6)

Hitch, Ch. J.; McKean, R. N. 1975. The Economics in the Nuclear Age. New York: Atheneum.

Ivančík, R. 2012. Allocative and Technical Efficiency of Defense Funding in the Slovak Republic. Liptovský Mikuláš: Akadémia ozbrojených síl gen. M. R. Štefánika.

Kanter, H. 1984. Defense Economics 1776 - 1983. Armed Forces and Society, 10(3): 426-448.

Kazanský, R. 2015. The Theory of Conflict. Banská Bystrica : Belianum.

Kennedy, G. 1983. Defence Economics. London: Duckworth.

Lasicová, J.; Ušiak, J. 2012. Safety as a Category. Bratislava: VEDA.

Medved', J.; Nemec, J. et al. 2011. Public Finance. Bratislava: Sprint dva.

Mouraud, A. 2017. Innovative time series forecasting: auto regressive moving average vs deep networks, Entrepreneurship and Sustainability Issues 4(3): 282-293. http://dx.doi.org/10.9770/jesi.2017.4.3S(4)

Rezk, M. A.; Ibrahim, H. H.; Tvaronavičienė, M.; Sakr, M. M.; Piccinetti, L. 2015. Measuring innovations in Egypt: case of industry, Entrepreneurship and Sustainability Issues 3(1): 47-55. http://dx.doi.org/10.9770/jesi.2015.3.1(4)

Samuelson, P. A.; Nordhaus, W. D. 2010. Economics. Praha: Svoboda.

Šefč́ik, V. 1999. Economics and Defence of the State. Praha: MO ČR.

SIPRI. 2016. SIPRI Military Expenditures Database. Available on the Internet: < https://www.sipri.org/ databases/milex $>$

SITA. 2014. President with the Prime Minister accepted the Secretary General of NATO. Pravda. Available on the Internet: $<$ http://spravy.pravda.sk/domace/clanok/317741-prezident-prijal-generalneho-tajomnika-nato>

Sivák, R. et al. 2007. Public Finance. Bratislava: Iura Edition.

Smith, A. 2001. An Inquiry into the Nature and Causes of the Wealth of Nations. Praha: Liberální institut.

Stankevičius, A.; Lukšaitè, A. 2016. Transparent lobbying for sustainability: case of Lithuania, Entrepreneurship and Sustainability Issues 4(2): 220-227. http://dx.doi.org/10.9770/jesi.2016.4.2(9)

Stiglitz, J. E. 1997. Economics of the Public Sector. Praha: Grada Publishing.

Strecková, Y. 1998. The Theory of Public Sector. Brno: Masarykova univerzita.

Vaško, M.; Abrhám, J. 2015. Issues of secure and sustainable e-tourism: case of the Czech Republic, Journal of Security and Sustainability Issues 5(2): 137-148. http://dx.doi.org/10.9770/jssi.2015.5.2(1)

\section{Information about Authors:}

Radoslav Ivančík (Colonel GS, Dipl. Eng., PhD. \& PhD.) is Director General of the Department of Human Resources at the Ministry of Defence of the Slovak Republic. He holds a Master Degree in Economy of Defence, a Doctorate Degree in Security and Defence of the State, and simultaneously another in Economy of Public Sector, and is a graduate of the U.S. Naval Postgraduate School in Defence Resource Management. He is an author and co-author of many monographs, university books, studies and articles in the area of security and defence.

ORCID ID: 0000-0003-2233-1014 
Pavel Nečas (Colonel GS ret., Prof. Dipl. Eng., PhD.) is an active rector of the University of Security Management. He holds a Master Degree in Command, Control, Communication and Information Systems, a Doctorate Degree in Operational and Tactical Deployment of the Air Force and Air Defence, and is a graduate of the U.S. Air Command and Staff College. He is an author and co-author of many monographs, university books, studies and articles in the area of security and defence.

ORCID ID: 0000-0001-7743-0453 